\title{
Correlation of Insulin-Like Growth Factor-I and -II Concentrations at Birth Measured by Mass Spectrometry and Growth from Birth to Two Months
}

\author{
Colin P. Hawkes ${ }^{a-c}$ Deirdre M. Murray ${ }^{c, d}$ Louise C. Kenny ${ }^{d, e}$ Mairead Kielyd, $f$ \\ Jonathan O'B Hourihane ${ }^{c, d}$ Alan D. Irvine ${ }^{b, g}$ Zengru Wu ${ }^{\text {h }}$ Yair Argon $^{\mathrm{i}}$ \\ Richard E. Reitz ${ }^{h}$ Michael J. McPhaul ${ }^{\text {h }}$ Adda Grimberg $^{\mathrm{a}, \mathrm{j}}$ \\ a Division of Endocrinology and Diabetes, The Children's Hospital of Philadelphia, Philadelphia, PA, USA; ${ }^{\mathrm{b}}$ The National \\ Children's Research Centre, Dublin, Ireland; ' $D$ Department of Paediatrics and Child Health, University College Cork, Cork, \\ Ireland; ${ }^{\mathrm{d}}$ The Irish Centre for Fetal and Neonatal Translational Research, Cork, Ireland; ${ }^{\mathrm{e}}$ Department of Obstetrics and \\ Gynaecology, University College Cork, Cork, Ireland; 'School of Food and Nutritional Science, University College Cork, Cork, \\ Ireland; ${ }^{9}$ Department of Clinical Medicine, Trinity College Dublin, Dublin, Ireland; h Quest Diagnostics Nichols Institute, San \\ Juan Capistrano, CA, USA; 'Department of Pathology and Laboratory Medicine, University of Pennsylvania, Philadelphia, PA, \\ USA; ${ }^{j}$ Department of Pediatrics, Perelman School of Medicine, University of Pennsylvania, Philadelphia, PA, USA
}

\section{Keywords}

IGF-I - IGF-II · Assay · Mass spectrometry · Growth hormone

\begin{abstract}
Background: Immunoassays used to measure insulin-like growth factor (IGF)-I and-II concentrations are susceptible to interference from IGF-binding proteins. The aim of this study was to investigate the association of IGF-I and -II concentrations at birth with neonatal anthropometry using a liquid chromatography/mass spectrometry (LCMS) assay. Methods: LCMS was used to measure IGF-I and -II concentrations in umbilical cord blood of term, healthy infants enrolled in the Cork BASELINE Birth Cohort Study. Weight, length, and occipitofrontal head circumference (OFC) were measured at birth and 2 months. Results: Cord blood IGF-I and -II concentrations were measured in 1,100 infants. Mean (SD) IGF-I and -II concentrations were 52.5 (23.9) ng/mL and 424.3 (98.2) $\mathrm{ng} / \mathrm{mL}$, respectively. IGF-I and -II concentrations at birth
\end{abstract}

\section{KARGER}

(c) 2018 S. Karger AG, Basel

E-Mail karger@karger.com

www.karger.com/hrp were associated $(p<0.05)$ with weight $\left(R^{2}=0.19, R^{2}=0.01\right)$, length $\left(R^{2}=0.07, R^{2}=0.004\right)$, and OFC $\left(R^{2}=0.03, R^{2}=0.04\right)$ at birth. Low IGF-I concentrations at birth were associated with increases in weight $(p<0.001)$ and OFC $(p<0.01) Z$ scores in the first 2 months. Conclusion: Using an LCMS assay, we have shown that anthropometric parameters at birth are associated with IGF-I and weakly with IGF-II concentrations. This indicates that, at the time of birth, IGF-I is the more important growth factor for regulating infant growth.

(c) 2018 S. Karger AG, Basel

\section{Background}

The growth hormone (GH)/insulin-like growth factor (IGF) axis is a key regulator of postnatal human growth. Although IGF-I and -II are under the influence of GH secretion in the older child [1], prenatal regulation of these factors is less dependent on GH production [2]. Conse- 
quently, congenital GH deficiency is associated with normal size at birth [3], while mutations affecting IGF-I [4, 5] and IGF-II $[6,7]$ signaling affect birth size in humans and mouse models, with up to $60 \%$ reductions $[8,9]$.

Numerous factors outside of the GH/IGF axis may influence prenatal IGF-I and -II production. Umbilical cord blood samples from female infants have higher IGFI concentrations than from males [10]. Maternal factors such as cigarette smoking [11], obesity [12], and preeclampsia $[13,14]$ may also affect IGF concentrations, although most studies to date have focused on IGF-I and not IGF-II measurements. Furthermore, small studies have demonstrated a correlation between cord blood IGF-I concentration and birth size [15-17], but the association for IGF-II is reported to be weak or absent $[16,18$, 19].

Over $90 \%$ of circulating IGF-I and -II is bound to IGFbinding proteins (IGFBPs), prolonging their serum halflife and regulating their bioavailability. Prior to measurement, IGF-I and -II must be separated from these IGFBPs, and extraction methods such as acid ethanol precipitation are commonly used [20]. This approach recovers only $75-80 \%$ of the IGF-I complexed to IGFBPs [21], and may affect the reliability of the reported measurements. This interference is likely to be more problematic in infants, who have lower IGF concentrations and higher concentrations of some of the IGFBPs than older children [22]. For example, IGFBP-1 concentrations can be increased by the stress of labor $[23,24]$, or in pregnancies complicated by preeclampsia [14], and it is likely that interference will significantly affect IGF measurement accuracy when susceptible assays are used. Differences in IGF-I measurements also have been attributed to their reliance on different reference populations, resulting in assay-specific reference ranges, but a study of six IGF-I immunoassays using the same healthy population-based reference samples still yielded different assay-specific reference ranges with variations most noticeable at higher IGF-I concentrations [25].

Liquid chromatography/mass spectrometry (LCMS) assays are now available to measure IGF-I and -II concentrations [26], a method that is less susceptible to IGFBP interference even in the presence of supraphysiological levels of IGFBP-3 [27]. Isotopically labeled IGF-I can be used with the LCMS assay to adjust for the IGF-I and -II lost in acid ethanol extraction and chromatography, further improving the accuracy of this method. We hypothesized removing IGFBP interference from IGF-I and -II measurement at birth would allow us to study the relationship between IGF-I and -II concentrations with size at birth and early infant growth. The aim of this study was to explore the relationships of age- and gestational agecorrected umbilical cord IGF-I and -II concentrations measured at birth by LCMS with weight, length, and occipitofrontal head circumference (OFC) at birth and 2 months.

\section{Methods}

The Cork BASELINE birth cohort includes healthy Irish children born between August 2008 and August 2011 (ClinicalTrials. gov NCT: 01498965). A detailed description of this cohort has been reported previously [28]. Firstborn children of singleton pregnancies born to low-risk mothers were included in this study. Exclusion criteria were maternal prepregnancy hypertension, prepregnancy or gestational diabetes, renal disease, systemic lupus erythematosus, antiphospholipid syndrome, major uterine anomalies, major fetal anomalies, cervical cone biopsy, and $\geq 3$ miscarriages. The Clinical Research Ethics Committee of the Cork Teaching Hospitals approved this study procedures and protocol, and parental consent was provided for participation.

Subjects

For this study, all children born between 37 and 42 weeks' gestation were included. Gestational age was determined by the first day of the last menstrual period. If fetal ultrasound was performed before 16 weeks' gestation and a discrepancy of greater than 6 days was noted, ultrasonographic gestational age was used. Similarly, gestational age was determined by ultrasound if performed up to 21 weeks' gestation and a discrepancy of 10 days was noted. Smoking status during the first trimester was ascertained by self-report during pregnancy.

\section{Anthropometry}

Weight, length, and OFC were measured on the first day of life using standardized protocols. A Harpenden neonatometer (Harlow Healthcare, London, UK) was used to measure supine length, and naked weight was measured using the Seca 384 Baby Scales (Seca, Hamburg, Germany). Sex- and gestational age-specific $Z$ scores for weight, length, and OFC were generated from the UK reference charts [29] using Stata 12.0 (StataCorp, TX, USA) [30]. Subjects were measured again at 2 months of age using the same standardized protocols.

\section{Sample Collection and Storage}

Umbilical cord blood samples were collected at birth and processed to serum within $3 \mathrm{~h}$ of collection. They were stored at $-80^{\circ} \mathrm{C}$ until analysis.

\section{Mass Spectrometry}

IGF-I and -II concentrations were measured by Quest Diagnostics (San Juan Capistrano, CA, USA) using LCMS, in an approach described in detail elsewhere [27, 31]. Isotopically labeled IGF-I was added to the sample as an internal standard for IGF-I and -II. IGF-I and -II were released from their binding proteins by an acid ethanol extraction followed by automated online extraction and analytical chromatography using an Aria TX-4 (Thermo- 
Table 1. Characteristics of the infants and pregnancies included in this cohort

\begin{tabular}{lccc}
\hline & Male & Female & All \\
\hline Infants, $n$ & 563 & 537 & 1,100 \\
Caucasian, $n$ & 555 & 527 & 1,082 \\
Gestational age, weeks & $40.1(1.1)$ & $40.2(1.1)$ & $40.2(1.1)$ \\
Weight at birth, kg & $3.55(0.47)$ & $3.48(0.44)$ & $3.52(0.45)$ \\
Length at birth, cm & $50.7(2.1)$ & $50.2(1.9)$ & $50.4(2)$ \\
Head circumference at birth, cm & $35.1(1.4)$ & $34.6(1.3)$ & $34.9(1.4)$ \\
Umbilical cord IGF-I, ng/mL & $48.5(23.2)$ & $56.7(23.9)$ & $52.5(23.9)$ \\
Umbilical cord IGF-II, ng/mL & $420.8(95)$ & $428(101.4)$ & $424.3(98.2)$ \\
Maternal age, years & $30.1(4.6)$ & $30(4.2)$ & $30.1(4.4)$ \\
Maternal BMI at 15 weeks & $24.8(4.1)$ & $24.9(4.2)$ & $24.9(4.1)$ \\
Maternal smoking during first trimester, $n$ & 145 & 132 & 277 \\
\hline
\end{tabular}

Values of all continuous variables are presented as mean (SD).

Fisher, San Jose, CA, USA). IGF-I and -II were quantitated using a time-of-flight mass spectrometer using narrow mass extraction of full-scan spectra. The internal standard was used to adjust for any procedural losses during extraction.

Performance characteristics of this assay have been previously described [27, 31]. For IGF-I using quality control samples, the interassay coefficient of variation and percent recovery were 5 and $104 \%$ at $100 \mathrm{ng} / \mathrm{mL}, 5.2$ and $103 \%$ at $400 \mathrm{ng} / \mathrm{mL}$, and 3.5 and $103 \%$ at $700 \mathrm{ng} / \mathrm{mL}$. For IGF-II, the interassay coefficient of variation and percent recovery were 6.1 and $102 \%$ at $200 \mathrm{ng} / \mathrm{mL}, 3.2$ and $99 \%$ at $500 \mathrm{ng} / \mathrm{mL}$, and 5.3 and $99 \%$ at $1,200 \mathrm{ng} / \mathrm{mL}$. Similar performance was seen with serum pools $[27,31]$.

\section{Statistical Analysis}

The lower limit of detection of IGF-I using this assay is $16 \mathrm{ng} /$ $\mathrm{mL}$; samples with concentrations below this limit were assigned a value of $15 \mathrm{ng} / \mathrm{mL}$. Similarly, the lower limit of detection of IGF-II was $32 \mathrm{ng} / \mathrm{ml}$; samples with concentrations below $32 \mathrm{ng} / \mathrm{mL}$ were assigned a value of $31 \mathrm{ng} / \mathrm{mL}$.

Sex-specific reference curves for IGF-I and IGF-II concentrations were generated using LMS Chartmaker Pro (Harlow Printing Ltd., South Shields, UK). The LMS method [32,33] uses a Box-Cox transformation to obtain normality. Three distinct curves were generated for skewness, median, and variability. These were combined in one graph, with smoothening of changes over time. They were then adjusted until fit of the curve was visually optimized as per software recommendations. IGF-I and IGF-II concentrations were then converted to age- and sex-specific $Z$-scores from this population for subsequent analysis.

Data analyses were performed using SPSS 22.0 (IBM, New York, NY, USA). Normally distributed data were described as mean (SD) and compared using independent-sample $t$ tests. Linear regression analysis was used to determine the relationship between continuous variables. Multiple linear regression analysis was performed to determine the relationship of IGF-I or -II Zscores at birth with the infant's weight, length, head circumference, and gestational age at birth and maternal BMI.

\section{Results}

A total of 1,100 term infants (563 male) met the inclusion criteria for this study. Characteristics of the population are shown in Table 1. The mean (SD) IGF-I concentration was $52.5(23.9) \mathrm{ng} / \mathrm{mL}$ (males $48.5[23.3] \mathrm{ng} / \mathrm{mL}$, females 56.7 [23.9] ng/mL). The mean (SD) IGF-II concentration was $424.3(98.2) \mathrm{ng} / \mathrm{mL}$ (males 420.8 [95] ng/ $\mathrm{mL}$, females $428[101.4] \mathrm{ng} / \mathrm{mL}$ ). There was a significant difference between males and females in IGF-I $(p<0.001)$ but not in IGF-II concentrations $(p=0.2)$.

Linear regression analysis showed a slight reduction in IGF-I concentrations with increasing gestational age in both males (regression coefficient [SEM] -0.005 [0.002], $p=0.01$ ) and females (regression coefficient [SEM] -0.004 [0.002], $p=0.03$ ). Gestational age was not associated with IGF-II concentrations in either males (regression coefficient $[\mathrm{SEM}] 0[0], p=0.4$ ) or females (regression coefficient [SEM] $0.001[0], p=0.06$ ). IGF-I and -II concentrations in term male and female infants according to gestational age are presented in Figure 1.

\section{Correlation with Anthropometry and Early Growth}

$Z$-scores for gestational age- and sex-specific IGF-I concentrations at birth correlated with weight, length, and OFC $Z$-scores at birth. The strongest association was with birth weight $\left(R^{2}=0.19\right)$. Length and weight $Z$-scores at age 2 months correlated significantly with IGF-I concentrations at birth, but the strength of the association was lower than at birth. Over 2 months, weight $R^{2}$ decreased from 0.19 to 0.02 and length $R^{2}$ decreased from 0.07 to 0.04 . Although IGF-II concentrations correlated 


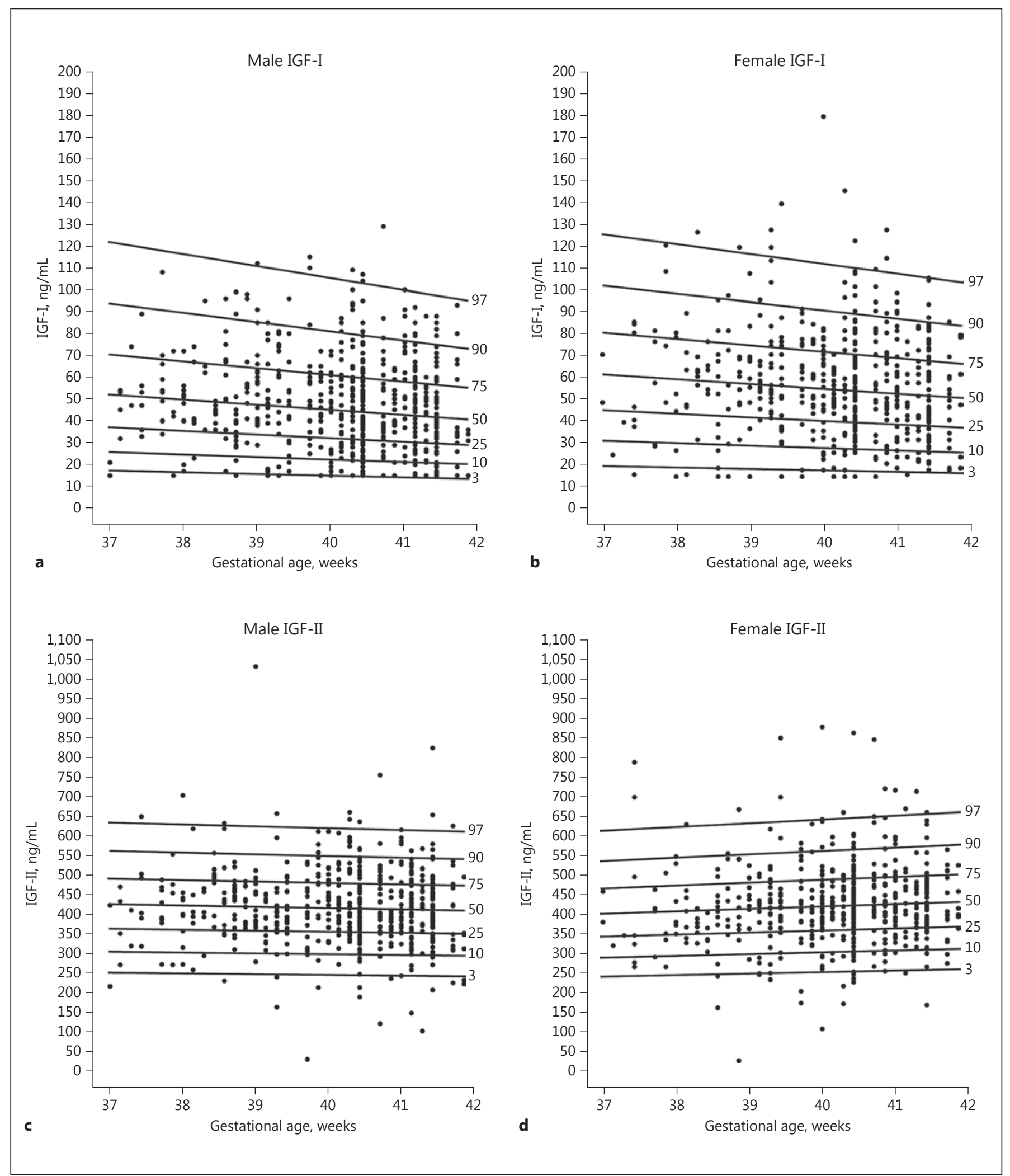

Fig. 1. Sex-specific centile charts for IGF-I (a, b) and IGF-II (c, d) concentrations in term infants in a healthy population-based cohort, according to gestational age from 37 to 42 weeks' gestation.

Pediatric Normative IGF-I and -II by Mass Spectrometry
Horm Res Paediatr 2018;89:122-131 DOI: $10.1159 / 000486035$ 
Table 2. The relationship between sex- and gestational age-corrected IGF-I and IGF-II $Z$-scores and growth parameters at birth and 2 months, and growth trajectory from birth to 2 months

\begin{tabular}{|c|c|c|c|c|c|c|}
\hline & \multicolumn{3}{|l|}{ IGF-I } & \multicolumn{3}{|c|}{ IGF-II } \\
\hline & $R^{2}$ & $\begin{array}{l}\text { regression } \\
\text { coefficient (SEM) }\end{array}$ & $p$ & $R^{2}$ & $\begin{array}{l}\text { regression } \\
\text { coefficient (SEM) }\end{array}$ & $p$ \\
\hline \multicolumn{7}{|l|}{$Z$-scores at birth } \\
\hline Length & 0.07 & $0.28(0.031)$ & $<0.001$ & 0.004 & $0.071(0.033)$ & 0.03 \\
\hline Weight & 0.19 & $0.51(0.032)$ & $<0.001$ & 0.005 & $0.088(0.036)$ & 0.01 \\
\hline Head circumference & 0.028 & $0.174(0.03)$ & $<0.001$ & 0.004 & $0.066(0.032)$ & 0.04 \\
\hline \multicolumn{7}{|l|}{$Z$-scores at 2 months } \\
\hline Length & 0.04 & $0.206(0.032)$ & $<0.001$ & 0.004 & $0.069(0.033)$ & 0.04 \\
\hline Weight & 0.022 & $0.152(0.033)$ & $<0.001$ & 0.002 & $0.048(0.034)$ & 0.16 \\
\hline Head circumference & 0.001 & $0.04(0.035)$ & 0.24 & 0.003 & $0.063(0.035)$ & 0.06 \\
\hline \multicolumn{7}{|c|}{ Delta Z-score from birth to 2 months } \\
\hline Length & 0.002 & $-0.05(0.04)$ & 0.14 & 0.001 & $0.01(0.04)$ & 0.8 \\
\hline Weight & 0.07 & $-0.31(0.04)$ & $<0.001$ & 0.001 & $-0.03(0.04)$ & 0.4 \\
\hline Head circumference & 0.02 & $-0.17(0.04)$ & $<0.001$ & 0.001 & $-0.02(0.04)$ & 0.5 \\
\hline
\end{tabular}

Length, weight, and head circumference are presented as sex-, age-, and gestation age-corrected $Z$-scores. For this analysis, IGF-I and -II are the dependent variables and anthropometric measures are independent variables.

Table 3. Multiple linear regression analysis of IGF-I and -II Z-scores at birth with birth weight, length, and head circumference, gestational age, and maternal BMI at 15 weeks

\begin{tabular}{|c|c|c|c|c|c|c|}
\hline & \multicolumn{3}{|c|}{ IGF-I $Z$-score $\left(R^{2}=0.21\right)$} & \multicolumn{3}{|c|}{ IGF-II $Z$-score $\left(R^{2}=0.01\right)$} \\
\hline & $\mathrm{B}$ & SE & $p$ & B & SE & $p$ \\
\hline Weight $Z$-score at birth & 0.66 & 0.05 & $<0.001$ & 0.04 & 0.06 & 0.5 \\
\hline Length $Z$-score at birth & -0.04 & 0.38 & 0.3 & 0.03 & 0.04 & 0.5 \\
\hline Head circumference $Z$-score at birth & -0.15 & 0.03 & $<0.001$ & 0.03 & 0.04 & 0.4 \\
\hline Maternal BMI at 15 weeks & -0.02 & 0.01 & 0.01 & 0.01 & 0.01 & 0.1 \\
\hline Gestational age & 0.12 & 0.03 & 0.6 & 0.01 & 0.03 & 0.7 \\
\hline
\end{tabular}

significantly with weight, length, and OFC at birth, this accounted for $<1 \%$ of the variance seen in each of these parameters (Table 2). Multiple linear regression analysis including these measurements at birth with maternal BMI at 15 weeks' gestation and gestational age increased the $R^{2}$ for IGF-I to 0.21 and for IGF-II $Z$-score to 0.01 (Table 3).

Both IGF-I and -II concentrations at birth were associated with length at age 2 months $(p<0.001$ and $p=0.04$, respectively), while only IGF-I concentration at birth was associated with weight at 2 months $(p<0.001)$. The rates of change in OFC and weight $Z$-scores over the first 2 months of life were negatively associated with IGF-I con- centrations at birth. IGF-II concentrations at birth were not associated with growth trajectories in weight, length, or OFC over the first 2 months (Fig. 2).

An increase in weight, OFC, and length $Z$-score of 1 or more over the first 2 months was seen in 198, 250, and 343 infants, respectively. Those with an increase in weight $Z$ score of 1 or more had significantly lower mean IGF-I $Z$ scores at birth ( -0.6 vs. $0.1, p<0.001)$, but not IGF-II $Z$ scores $(-0.06$ vs. $0.02, p=0.4)$. Similarly, infants with an increase in OFC $Z$-score during the first 2 months tended to have lower IGF-I $Z$-scores $(-0.2$ vs. $0.05, p=0.003)$ but not IGF-II $Z$-scores $(-0.08$ vs. $0.02, p=0.2)$. No difference was seen in IGF-I $(p=0.9)$ or IGF-II $(p=0.9) Z$-scores at 
Table 4. Comparison of gestational age- and sex-corrected mean (SD) Z-scores for IGF-I and -II, according to history of maternal smoking, maternal obesity, preeclampsia, or length, weight or head circumference at birth

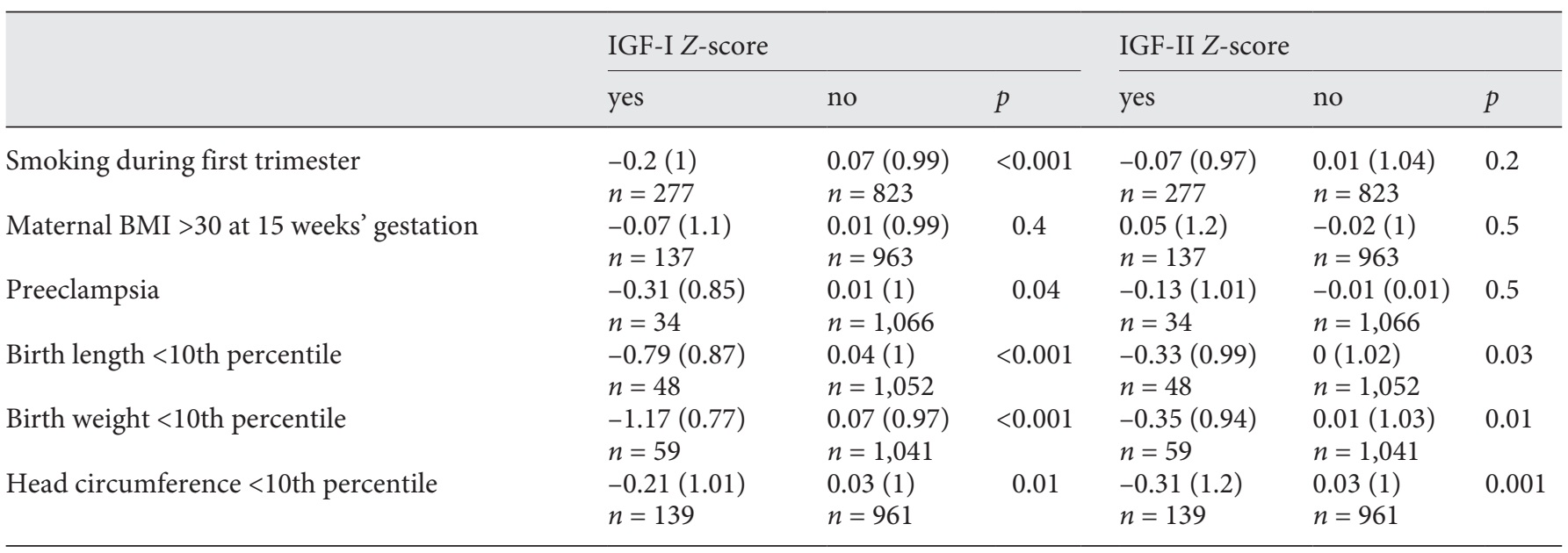

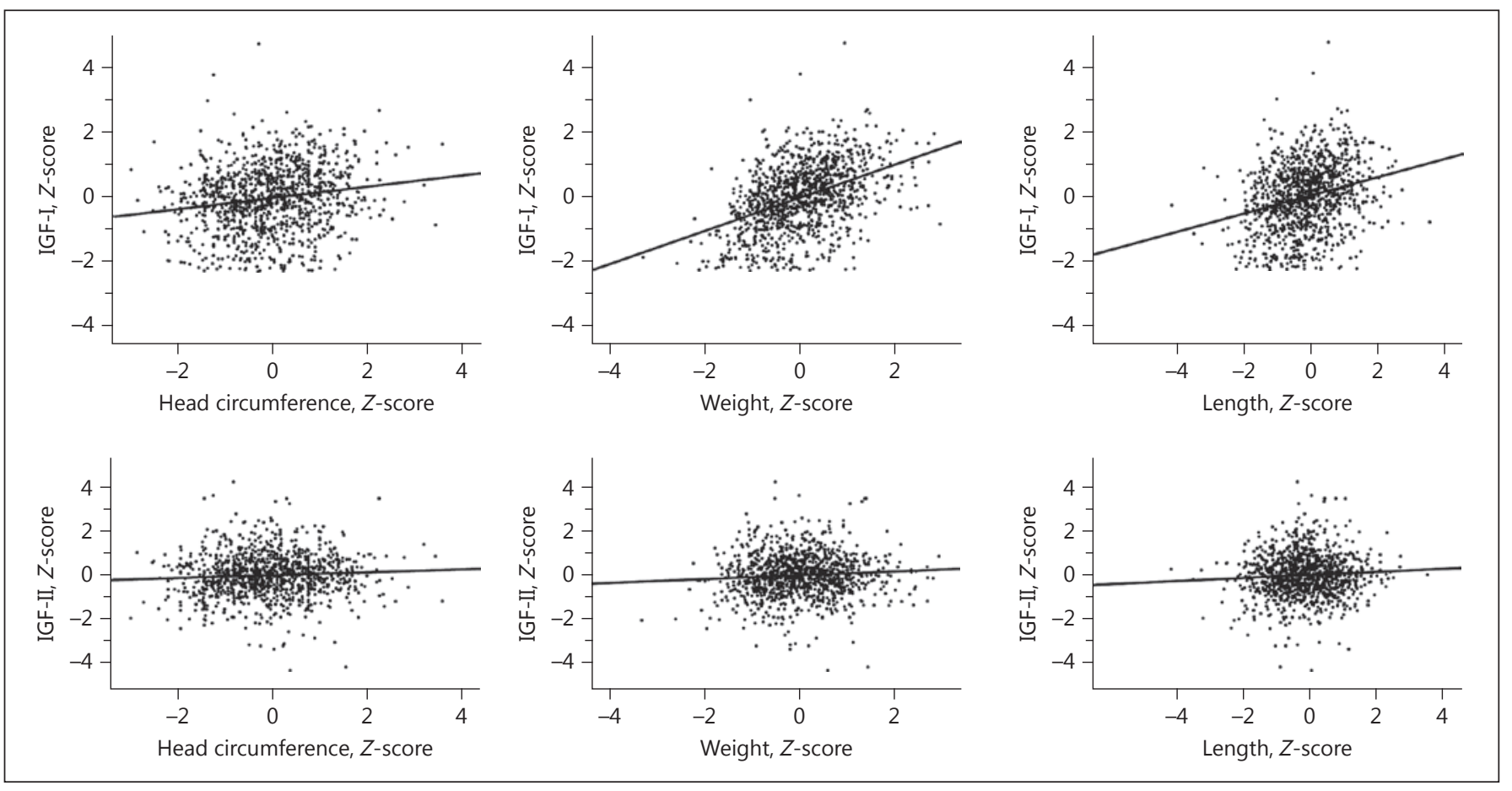

Fig. 2. The relationship between IGF-I and -II Z-scores at birth with head circumference, weight, and length $Z$ scores at birth.

birth in infants who had an increase in length $Z$-score of 1 or more. Lower mean (SD) birth weight $Z$-scores were seen in infants with increases in weight ( -0.5 vs. $0.1, p<$ $0.001)$, length ( -0.08 vs. $0.09, p<0.001)$, and OFC $(-0.3$ vs. $0.1, p<0.001) Z$-scores of 1 or more in the first 2 months.

Pediatric Normative IGF-I and -II by Mass Spectrometry

\section{Factors Influencing IGF Concentrations}

Of the 1,100 infants included in this study, 40 had birth length and 57 had birth weight below the 10th percentile. In those with birth length below the 10th percentile, IGFI $Z$-scores $(-0.7$ vs. $0.1, p<0.001)$ and IGF-II $Z$-scores $(-0.3$ vs. $0, p=0.03)$ at birth were lower (Fig. $3 d)$. This was

Horm Res Paediatr 2018;89:122-131 


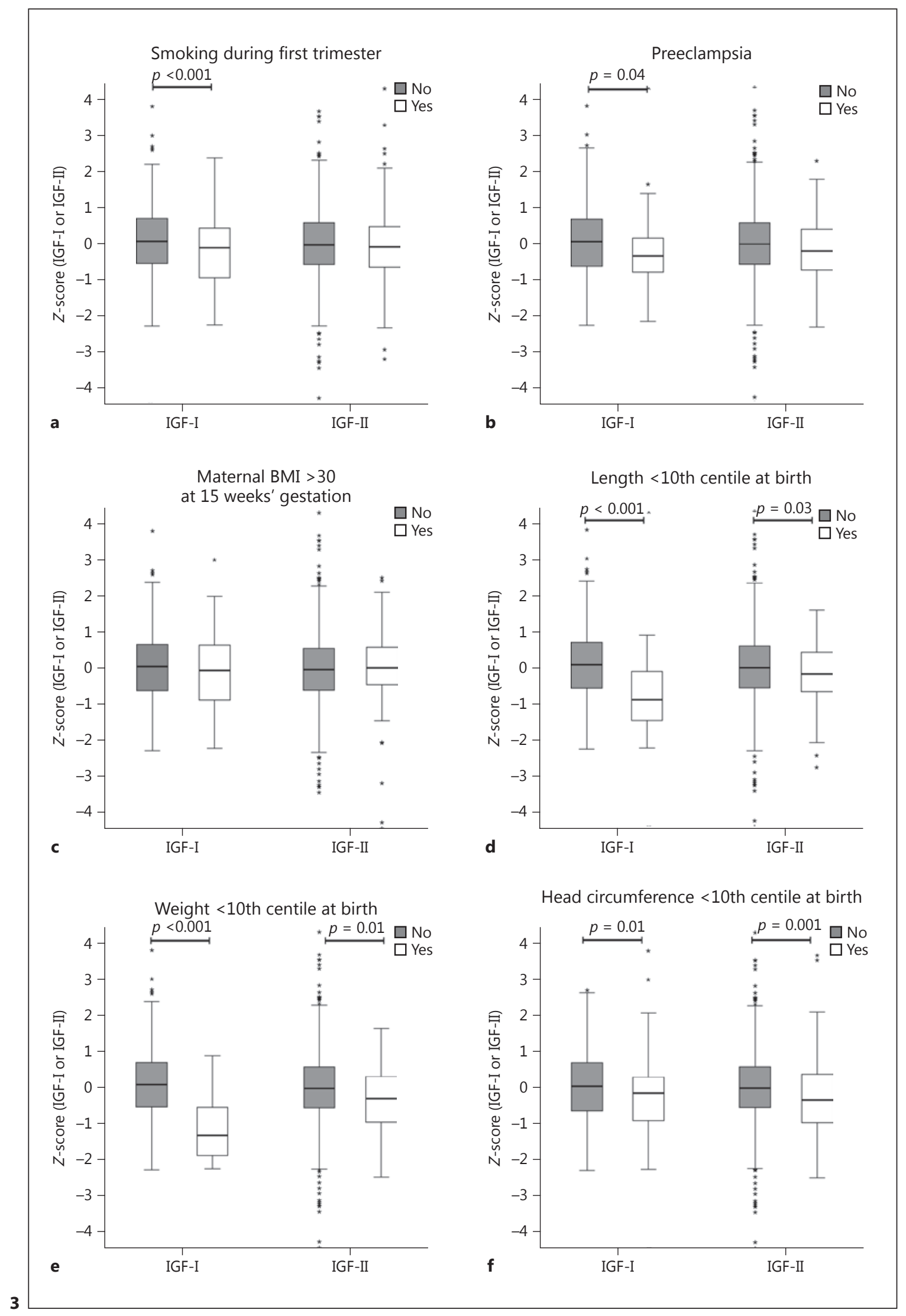

(For legend see next page.) 
also seen in infants with birthweight below the 10th percentile (IGF-I $Z$-scores -1.2 vs. $0.07, p<0.001$; IGF-II $Z$ scores -0.4 vs. $0, p=0.01$ ) (Fig. 3 e).

Maternal cigarette smoking during the first trimester and preeclampsia were associated with lower mean (SD) cord IGF-I concentrations ( $p<0.001$ and $p=0.04$, respectively) but not IGF-II concentrations ( $p=0.2$ and $p=0.5$, respectively). Maternal BMI $>30(n=137)$ at 15 weeks' gestation was not associated with increased umbilical cord IGF-I or -II concentrations ( $p=0.4$ and 0.5 , respectively) (Table 4).

\section{Discussion}

We have described the largest reported population of infants with IGF-I and -II concentrations measured at birth using LCMS. We have used an LCMS assay that is less susceptible to IGFBP interference [27], thus generating accurate measurements at an age where IGF-I concentrations tend to be low. Our large cohort of well-characterized term infants allowed us to investigate the relationship between these measurements and birth size and early infant growth. Consistent with previous studies using other assays, IGF-I and -II concentrations at birth were associated with weight, length, and OFC at birth. At age 2 months, weight and length were associated with birth IGF-I concentrations whereas only length was associated with birth IGF-II concentrations. Low IGF-I concentrations at birth were associated with accelerated increases in weight and OFC $Z$-scores over the first 2 months. Maternal smoking and preeclampsia were associated with lower cord IGF-I but not IGF-II concentrations.

The correlation of an infant's birth weight and length with IGF-I concentration has been shown previously in smaller studies using radioimmunoassays $[11,16,19,34$, 35]. The relationship between birth weight and IGF-II levels are less well defined, with some studies showing no correlation $[35,36]$. Our results support the findings of other studies, where a weak association has been shown $[16,37]$. This weak association between cord IGF-II and neonatal anthropometry is surprising given the signifi-

Fig. 3. The effect of smoking (a), preeclampsia (b), and maternal obesity (c) on umbilical cord IGF-I and -II age- and-sex specific $Z$-scores. The association of birth length (d), birth weight $(\mathbf{e})$, and head circumference $(\mathbf{f})$ below the 10th centile with cord IGF-I and -II concentrations are also shown.

Pediatric Normative IGF-I and -II by Mass Spectrometry cant effect of mutations affecting IGF-II signaling on mouse [8] and human [6,7] size at birth. Possible explanations for this include a potential neutralizing effect of circulating IGF-II receptors on the bioavailability of circulating IGF-II [16]. This interference may be of clinical significance but it does not affect IGF-II measurement by LCMS. Alternatively, IGF-II may be more important in regulating growth prior to the third trimester [38, 39], and IGF-II concentrations at birth may be clinically less significant.

Infants with lower IGF-I concentrations at birth had a greater change in weight and OFC over the first 2 months of life. The mechanism of this effect is unclear, but this finding may be related to low IGF-I concentrations being a marker of nutritional status [40]. Umbilical cord leptin concentration is a marker of nutritional status at birth and an inverse relationship also is seen between early growth and cord leptin [41]. IGF-I concentrations at birth correlate with adiposity and cord leptin concentrations [42]. Thus, this may represent "catch-up" growth in infants born small for gestational age who initially have lower IGF-I concentrations.

Birth IGF-II concentrations do not correlate with early infant growth in any of these parameters, further supporting the interpretation that the role of IGF-II in fetal growth is less clinically significant by the time of birth.

Maternal smoking has been shown previously to be associated with reduced cord IGF-I concentrations in females [11]. However, we have shown that this effect is seen both in male and female infants. The interplay between IGF-I and -II and placental function may provide insight into this relationship. Placental vasculature is affected by maternal smoking, with reduced length of villous capillaries and decreased trophoblast volume [43]. This may affect nutrient availability to the fetus and subsequently reduce growth parameters and IGF-I concentrations. IGF-I and -II are both expressed in chorionic and basal plates of the placenta [44], and thus may play a key role in regulating placentation.

The main strengths of this study in evaluating the relationship between IGFs and infant size are the large number of healthy term infants included, and the use of an LCMS assay. This assay has been shown previously to be free from IGFBP interference when measuring IGF-I and -II concentrations [27]. A limitation of this study is that the Cork BASELINE birth cohort was a relatively homogenous population of Caucasian Irish healthy term infants. Consequently, it is not known if the reference data can be applied directly to other patient populations. This may be particularly important when considering the sig-

Horm Res Paediatr 2018;89:122-131 
nificant effect of smoking during the first trimester on cord IGF-I concentrations, as a maternal cigarette use occurred during a quarter of pregnancies included here. IGF-I concentrations may be marginally higher in populations with lower rates of cigarette smoking, such as America, where $13 \%$ of all females smoke [45]. In addition, our findings are only applicable to term infants and it is not known if the associations are also seen in preterm infants. Not all infants in this cohort had cord blood available for analysis, and it is not known if this introduced bias to our study, although this is unlikely as our findings are generally consistent with previous smaller studies. A small number of subjects had IGF-I and -II concentrations below the detectable limits of the assay, and this may also have influenced our results.

In conclusion, this study has provided reference data for IGF-I and IGF-II concentrations at birth in term infants, as measured by LCMS. These data will be useful clinically, where prenatal defects of IGF production are suspected, and may support future research in evaluating the prenatal role of these growth factors. We recommend using the LCMS assay when measuring IGF-I and -II in conditions where IGFBP interference may significantly affect interpretation of results, particularly in young infants where IGF concentrations are generally low [22]. Using this assay, we have corroborated many of the previously known associations between IGF-I concentrations and anthropometry at birth, demonstrated a weaker but significant association between IGF-II and anthropometry at birth, and shown a negative association between IGF-I measurements at birth and change in weight or OFC over the first 2 months of life.

\section{Acknowledgement}

The authors would like to acknowledge Julia Larsen at Quest Diagnostics and Klaudia Sikora at University College Cork for sample handling and data retrieval.

\section{Disclosure Statement}

Financial Disclosure

A.G. serves on the Steering Committee of the Pfizer International Growth Study Database. Z.W., M.J.M., and R.E.R. are employees and stockholders of Quest Diagnostics. All other authors have no financial relationships relevant to this article to disclose.

\section{Conflicts of Interest}

The authors have no conflicts of interest to disclose.

\section{Funding Sources}

Dr. Hawkes is supported by a $\mathrm{PhD}$ grant by the National Children's Research Centre, Dublin, Ireland, and Dr. Grimberg was supported by grant 1R01 HD57037 from the Eunice Kennedy Shriver National Institute of Child Health and Human Development (NICHD). The SCOPE Ireland Study was funded by the Health Research Board of Ireland (CSA 02/2007). L.C.K. is a Science Foundation Ireland (SFI) principal investigator (PI) (08/ IN.1/B2083). L.C.K., D.M.M. J.O'B H., A.D.I. and M.K. are PIs in the SFI-funded Research Centre, INFANT (12/RC/2272). The Cork BASELINE birth cohort is funded by the National Children's Research Centre.

\section{References}

1 Aguiar-Oliveira $\mathrm{MH}$, Gill MS, de ABES, Alcantara MR, Miraki-Moud F, Menezes CA, Souza AH, Martinelli CE, Pereira FA, Salvatori R, Levine MA, Shalet SM, Camacho-Hubner C, Clayton PE: Effect of severe growth hormone $(\mathrm{GH})$ deficiency due to a mutation in the GH-releasing hormone receptor on insulin-like growth factors (IGFs), IGF-binding proteins, and ternary complex formation throughout life. J Clin Endocrinol Metab 1999;84:4118-4126.

2 Hawkes CP, Levitt Katz LE: Growth factor regulation of fetal growth; in Polin RA, Fox WW, Abman SH (eds): Fetal and Neonatal Physiology. Amsterdam, Elsevier/Saunders, 2016, pp 1461-1470.
3 Savage MO, Blum WF, Ranke MB, Postel-Vinay MC, Cotterill AM, Hall K, Chatelain PG, Preece MA, Rosenfeld RG: Clinical features and endocrine status in patients with growth hormone insensitivity (Laron syndrome). J Clin Endocrinol Metab 1993;77:1465-1471.

4 Abuzzahab MJ, Schneider A, Goddard A, Grigorescu F, Lautier C, Keller E, Kiess W, Klammt J, Kratzsch J, Osgood D, Pfaffle R, Raile K, Seidel B, Smith RJ, Chernausek SD; Intrauterine Growth Retardation Study Group: IGF-I receptor mutations resulting in intrauterine and postnatal growth retardation. N Engl J Med 2003;349:2211-2222.

5 Klammt J, Kiess W, Pfäffle R: IGF1R mutations as cause of SGA. Best Pract Res Clin Endocrinol Metab 2011;25:191-206.
6 St-Pierre J, Hivert MF, Perron P, Poirier P, Guay SP, Brisson D, Bouchard L: IGF2 DNA methylation is a modulator of newborn's fetal growth and development. Epigenetics 2012;7: 1125-1132.

7 Begemann M, Zirn B, Santen G, Wirthgen E, Soellner L, Buttel HM, Schweizer R, van Workum W, Binder G, Eggermann T: Paternally inherited IGF2 mutation and growth restriction. N Engl J Med 2015;373:349-356.

8 Baker J, Liu JP, Robertson EJ, Efstratiadis A: Role of insulin-like growth factors in embryonic and postnatal growth. Cell 1993;75:7382.

9 DeChiara TM, Robertson EJ, Efstratiadis A: Parental imprinting of the mouse insulin-like growth factor II gene. Cell 1991;64:849-859. 
10 Vatten LJ, Nilsen ST, Odegard RA, Romundstad PR, Austgulen R: Insulin-like growth factor I and leptin in umbilical cord plasma and infant birth size at term. Pediatrics 2002;109: 1131-1135.

11 Clifton VL, Hodyl NA, Murphy VE, Giles WB, Baxter RC, Smith R: Effect of maternal asthma, inhaled glucocorticoids and cigarette use during pregnancy on the newborn insulin-like growth factor axis. Growth Horm IGF Res 2010;20:39-48.

12 Vidal AC, Murtha AP, Murphy SK, Fortner K, Overcash F, Henry N, Schildkraut JM, Forman MR, Demark-Wahnefried W, Kurtzberg J, Jirtle R, Hoyo C: Maternal BMI, IGF-I levels, and birth weight in African American and white infants. Int J Pediatr 2013;2013:191472.

13 Christians JK, Gruslin A: Altered levels of insulin-like growth factor binding protein proteases in preeclampsia and intrauterine growth restriction. Prenat Diagn 2010;30: 815-820.

14 Vatten LJ, Odegard RA, Nilsen ST, Salvesen KA, Austgulen R: Relationship of insulin-like growth factor-I and insulin-like growth factor binding proteins in umbilical cord plasma to preeclampsia and infant birth weight. Obstet Gynecol 2002;99:85-90.

15 Rohrmann S, Sutcliffe CG, Bienstock JL, Monsegue D, Akereyeni F, Bradwin G, Rifai N, Pollak MN, Agurs-Collins T, Platz EA: Racial variation in sex steroid hormones and the insulin-like growth factor axis in umbilical cord blood of male neonates. Cancer Epidemiol Biomarkers Prev 2009;18:1484-1491.

16 Ong K, Kratzsch J, Kiess W, Costello M, Scott C, Dunger D: Size at birth and cord blood levels of insulin, insulin-like growth factor I (IGF-I), IGF-II, IGF-binding protein-1 (IGFBP-1), IGFBP-3, and the soluble IGF-II/ mannose-6-phosphate receptor in term human infants. The ALSPAC Study Team. Avon Longitudinal Study of Pregnancy and Childhood. J Clin Endocrinol Metab 2000;85:42664269.

17 Wiznitzer A, Reece EA, Homko C, Furman B, Mazor M, Levy J: Insulin-like growth factors, their binding proteins, and fetal macrosomia in offspring of nondiabetic pregnant women. Am J Perinatol 1998;15:23-28.

18 Shibata A, Harris DT, Billings PR: Concentrations of estrogens and IGFs in umbilical cord blood plasma: a comparison among Caucasian, Hispanic, and Asian-American females. J Clin Endocrinol Metab 2002;87:810-815.

19 Klauwer D, Blum WF, Hanitsch S, Rascher W, Lee PD, Kiess W: IGF-I, IGF-II, free IGF-I and IGFBP-1, -2 and -3 levels in venous cord blood: relationship to birthweight, length and gestational age in healthy newborns. Acta Paediatr 1997;86:826-833.
20 Daughaday WH, Parker KA, Borowsky S, Trivedi B, Kapadia M: Measurement of somatomedin-related peptides in fetal, neonatal, and maternal rat serum by insulin-like growth factor (IGF) I radioimmunoassay, IGF-II radioreceptor assay (RRA), and multiplication-stimulating activity RRA after acidethanol extraction. Endocrinology 1982;110: 575-581.

21 Blum WF, Breier BH: Radioimmunoassays for IGFs and IGFBPs. Growth Regul 1994; 4(suppl 1):11-19.

22 Hawkes CP, Grimberg A: Measuring growth hormone and insulin-like growth factor-I in infants: what is normal? Pediatr Endocrinol Rev 2013;11:126-146.

23 Wang HS, Lee JD, Soong YK: Effects of labor on serum levels of insulin and insulin-like growth factor-binding proteins at the time of delivery. Acta Obstet Gynecol Scand 1995;74: 186-193.

24 Hills FA, Crawford R, Harding S, Farkas A, Chard T: The effects of labor on maternal and fetal levels of insulin-like growth factor binding protein-1. Am J Obstet Gynecol 1994;171: 1292-1295.

25 Chanson P, Arnoux A, Mavromati M, BraillyTabard S, Massart C, Young J, Piketty ML, Souberbielle JC; VARIETE Investigators: Reference values for IGF-I serum concentrations: comparison of six immunoassays. J Clin Endocrinol Metab 2016;101:3450-3458.

26 Bredehoft M, Schanzer W, Thevis M: Quantification of human insulin-like growth factor-1 and qualitative detection of its analogues in plasma using liquid chromatography/electrospray ionisation tandem mass spectrometry. Rapid Commun Mass Spectrom 2008;22:477-485.

27 Bystrom C, Sheng S, Zhang K, Caulfield M, Clarke NJ, Reitz R: Clinical utility of insulinlike growth factor 1 and 2; determination by high resolution mass spectrometry. PLoS One 2012; 7:e43457.

28 O'Donovan SM, Murray DM, Hourihane JO, Kenny LC, Irvine AD, Kiely M: Cohort profile: The Cork BASELINE Birth Cohort Study: Babies after SCOPE: Evaluating the Longitudinal Impact on Neurological and Nutritional Endpoints. Int J Epidemiol 2014;44:764-775.

29 Cole TJ, Freeman JV, Preece MA: British 1990 growth reference centiles for weight, height, body mass index and head circumference fitted by maximum penalized likelihood. Stat Med 1998;17:407-429.

30 Vidmar SI, Cole TJ, Pan H: Standardizing anthropometric measures in children and adolescents with functions for egen: update. Stata J 2013;13:366-378.

31 Bystrom CE, Sheng S, Clarke NJ: Narrow mass extraction of time-of-flight data for quantitative analysis of proteins: determination of insulin-like growth factor-1. Anal Chem 2011;83:9005-9010.

32 Cole TJ: The LMS method for constructing normalized growth standards. Eur J Clin Nutr 1990;44:45-60.
33 Cole TJ, Green PJ: Smoothing reference centile curves: the LMS method and penalized likelihood. Stat Med 1992;11:1305-1319.

34 Simmons D: Interrelation between umbilical cord serum sex hormones, sex hormonebinding globulin, insulin-like growth factor I, and insulin in neonates from normal pregnancies and pregnancies complicated by diabetes. J Clin Endocrinol Metab 1995;80:22172221.

35 Osorio M, Torres J, Moya F, Pezzullo J, Salafia C, Baxter R, Schwander J, Fant M: Insulin-like growth factors (IGFs) and IGF binding proteins- $1,-2$, and -3 in newborn serum: relationships to fetoplacental growth at term. Early Hum Dev 1996;46:15-26.

36 Lassarre C, Hardouin S, Daffos F, Forestier F, Frankenne F, Binoux M: Serum insulin-like growth factors and insulin-like growth factor binding proteins in the human fetus. Relationships with growth in normal subjects and in subjects with intrauterine growth retardation. Pediatr Res 1991;29:219-225.

37 Samaan NA, Schultz PN, Pham FK: Insulinlike growth factor II and nonsuppressible insulin-like activity levels in newborns. Am J Obstet Gynecol 1990;163:1836-1839.

38 Langford K, Nicolaides K, Miell JP: Maternal and fetal insulin-like growth factors and their binding proteins in the second and third trimesters of human pregnancy. Hum Reprod 1998;13:1389-1393.

39 Langford K, Blum W, Nicolaides K, Jones J, McGregor A, Miell J: The pathophysiology of the insulin-like growth factor axis in fetal growth failure: a basis for programming by undernutrition? Eur J Clin Invest 1994;24: 851-856.

40 Hawkes CP, Grimberg A: Insulin-like growth factor-I is a marker for the nutritional state. Pediatr Endocrinol Rev 2015;13:465-477.

41 Chaoimh CN, Murray DM, Kenny LC, Irvine $\mathrm{AD}$, Hourihane JO, Kiely M: Cord blood leptin and gains in body weight and fat mass during infancy. Eur J Endocrinol 2016;175: 403-410.

42 Kadakia R, Ma M, Josefson JL: Neonatal adiposity increases with rising cord blood IGF-1 levels. Clin Endocrinol (Oxf) 2016;85:70-75.

43 Larsen LG, Clausen HV, Jonsson L: Stereologic examination of placentas from mothers who smoke during pregnancy. Am J Obstet Gynecol 2002;186:531-537.

44 Iniguez G, Gonzalez CA, Argandona F, Kakarieka E, Johnson MC, Cassorla F: Expression and protein content of IGF-I and IGF-I receptor in placentas from small, adequate and large for gestational age newborns. Horm Res Paediatr 2010;73:320-327.

45 World Health Organization: Tobacco: Data and Statistics. Copenhagen, WHO Regional Office for Europe, 2017.
Pediatric Normative IGF-I and -II by Mass Spectrometry
Horm Res Paediatr 2018;89:122-131 DOI: $10.1159 / 000486035$ 